\section{Challenges for the Future of Education brought by the Pandemic: The Coppead Case}

\author{
Desafios da Pandemia para o Futuro da Educação: O Caso Coppead
}

Discipline: Strategy and Innovation

Subject: Innovation, Ecosystems

Industry: Education

Geography: Rio de Janeiro/Brazil

\author{
Roberta Dias Campos ${ }^{1}$ \\ Elaine Tavares ${ }^{10}$ \\ Paula C. P. de Souza Chimenti ${ }^{1}$ (을 \\ Leonardo Marques ${ }^{1}$
}

\title{
INTRODUCTION
}

It was 10 o'clock in the morning, March 17, 2020 and Elaine Tavares, Coppead's director, was apprehensive. In a few minutes, she would start the Coppead Executive Board (EB) meeting with the participation of the entire faculty, student representatives, and staff. It was an extraordinary EB meeting that Elaine had called herself during which she would need to convince the teachers to urgently migrate their courses to a virtual environment. Her apprehension was justified because in the past Coppead had already tried, but without success, to convince the same teachers to move toward digital teaching models. Everyone understood that planning would be necessary for this change and that the majority would have to be convinced since the school has its main decisions based on the collegiate model.

The new driver for an immediate migration to online classes was the quarantine brought about by the spread of COVID-19, an unprecedented pandemic in the modern era that was forcing everyone to radically change their routines toward social distancing. With students and teachers needing to stay at home, the option of joining the remote classes would be the only alternative to not bring the school's teaching activities to a complete halt.

Elaine began the meeting by stating that the quarantine imposed due to COVID-19 brought a sense of urgency to the institution, which needed to decide quickly whether it would give classes online during that period. Immediately a teacher asked for the floor and stated that it was necessary to move quickly in this direction so as not to stop the master's, doctoral, and graduate courses currently in progress. By the expressions on the teachers' faces and from the heads nodding in agreement, Elaine realized that something had fundamentally changed and that her task would be easier than she had anticipated. 


\section{INNOVATION IN THE DNA}

Coppead was created in 1973 with resources from Finep, a funding authority for studies and projects from the Brazilian federal government under the Ministry of Science of Technology. Four Coppe professors ${ }^{1}$, Ney Brito, Paulo Fleury, Marcos Villela, and Moises Swirski, accepted the challenge and created a master's degree in administration based on the best MBAs in the world. It was a very small program and there was a huge difficulty in hiring teachers and in attracting students. The 12 students from the first class were recruited from Coppe and this first class had seven teachers. Some students who graduated were hired as teachers and the program also received many visiting professors and lecturers. The Coppead teachers began to promote the program across Brazil and the second class had 50 students.

Prof. Paulo Lemos, who had recently arrived at Coppead, went to Brasília to explain to Capes (Coordination for the Improvement of Higher Education Personnel) the importance of a master's degree in management with a focus on the market. Up until then the focus had only been on preparing academics, but he got to know the full-time MBA programs in North America aimed at a solid preparation of students to return to the market, and he recognized the importance of this model in graduate studies in administration, an applied social science. This has been Coppead's DNA ever since, an innovative school offering solid academic training driven by market practices.

In 1976, Prof. Paulo Lemos went to the United States to get to know executive MBA programs, recently being launched in that country. When he came back, he proposed creating the course because he realized that the program needed to have its own resources. The idea was finally brought to full fruition in 1982 when Coppead launched Brazil's first executive MBA.

Coppead created the Brazilian Case Center in 1980 and the case method started to become the core of Coppead's teaching framework. This was a result of the training given by Canadian teachers who came to Brazil to promote the method years before and of the discussions that the Coppead founders had in the United States on teaching methods. That was the same year that the school's doctoral program was instituted.

In 1984, Coppead created the research specialization program in the university-company relationship that provides private financing for the school's researches. In addition to providing resources for research, the model gives the school the opportunity to establish a relevant research agenda for the market and opens the doors of companies to research. The school depends on this program as an important source of funding and currently (2020) it has ten research specializations.

Coppead's history has been marked by innovation since its founding. The school was one of the first to establish a strong exchange program with international schools that in 2002 placed its master's degree in the Financial Times Ranking and has listed the course there several times since then with a business advisory board already being set up early in the 2000s. In 2015, the school began to have a full-time master's degree in English with regular foreign students because over time the institution also built an internationalization strategy.

Despite continuing to innovate over the years, some Coppead teachers recently wondered if the innovation pace was up to par. The concern to maintain excellence seemed to leave the school with a fear of making a mistake and any innovation had to prove relevant to replace products recognized as successful during the institution's history.

The school had a brief experience with technologymediated education, but there was a belief that there were considerable barriers to developing it properly, thus maintaining the teaching and learning method focused on the student, which is part of the school's philosophy and identity. The understanding of the school's teachers is that the students need to be the protagonist of their learning, which comes from all the classroom members and not just from the teacher. The school has always been based on a strict selection process for all its courses in order to make sure that the students in the classroom could also bring a strong contribution to the group.

A broad survey was started in the institution in 2019 in order to support new strategic fronts. There was a feeling that the classroom should incorporate more digital dimensions to meet the teaching demands for executives, but it was not yet clear how this could be linked to a pedagogy centered on the student and around debate and interaction, the institution's trademark.

How could this role of the student taking initiative be brought to the virtual environment? The path would have to include synchronous means of learning where the teacher could interact with the class in real time, challenging the students. And what would happen to the class networking, which is another aspect carefully built in the school? Caution was needed to navigate these seas. It was necessary to look into synchronous distance learning (DL) platforms, purchase a robust technological tool, and set up a consistent project for making sure that the school's teachers could continue to be proud of each lesson. 


\section{TECHNOLOGY AND NEW MOVEMENTS IN EDUCATION}

Innovations in the field of education have expanded the ecosystem well beyond the most traditional players of schools, publishers, students, teachers, and companies. In general, digital platforms have become a vector bringing greater potential to the initiatives of several new participants who expand, reinvent, or create new content and educational products. This movement has also enabled the diversification of the profile of those who began to work with executive education.

Beginning in 2012, traditional international schools such as Columbia, MIT, and Harvard began to offer short courses on online platforms that were announced on social media for the Brazilian public. Even the traditional MBA courses whose decline has been publicized for decades in the specialized press began to be designed into hybrid in-person and online models across several countries and combining asynchronous and digital weeks with face-toface and intensive meetings. In the Brazilian market, online courses bring partnerships between several institutions such as academic-business or international partnerships such as the Digital Renewal course offered by the Saint Paul School of Business in partnership with IBM or the PUC-RS online course portfolio put together with prominent personalities in the Brazilian and international business scene. In the Brazilian market, large educational institutions such as Estácio de Sá University have been active in offering DL courses, providing cheap and accessible training to a large number of students throughout the country.

Another emerging movement since 2012 have been the Massive Open Online Courses (MOOCs) such as Coursera, edX, Udemy, Future Learn, and Udacity. On these platforms, students anywhere in the world can have access to various content options in a simple and often cheaper way. Many of these platforms were created by traditional institutions that saw in this channel a new opportunity to reach students. $\mathrm{EdX}^{2}$, for example, was created by Harvard University and MIT as a nonprofit initiative offering free courses with payment only required to issue a certificate. Emeritus was founded by MIT, Columbia, and Tuck/Dartmouth with a focus on the business scenario offering unique and more expensive courses. Udemy, on the other hand, follows a marketplace logic offering broad and diverse options with more than 100,000 courses available at an affordable price. These initiatives compete with national examples such as Saint Paul's LIT platform built on a creatively designed artificial intelligence platform with digital content learning pills.

All of these initiatives work within the logic of micro-certifications, offering diplomas at every small achievement, thus adding value to the CV by showing the learning progress as in the example of edX's MicroMasters program that is supported by several companies. Players such as Google, HubSpot, and YouTube have also offered several courses with certification, energizing the segment. The various emerging certification initiatives have gradually created a new rule in the game of CVs in various areas such as marketing and finance.

New players that are not originally from the traditional educational segment have also ventured into offering alternative teaching solutions. The so-called Edtechs have recreated formats and reinvented the narrative of executive education. Some, such as the Be Academy ${ }^{3}$, taunt the disadvantages of academic environments and have invited market professionals to conduct their student learning experience. This offer is marked by the culture of startups and accelerators, stimulating short, hands-on, and intensive formats such as Tera's boot camps ${ }^{4}$. The promise of these offers is in not only breaking business paradigms, but also educational paradigms, reinventing the way you learn.

Consulting firms have also begun to invest in a training arm with examples such as McKinsey Academy or Accenture programs. Finally, publishers such as HSM Management ${ }^{5}$ are venturing into the industry offering courses in various formats. The sector also saw the entry of new players such as Descomplica, a fully digital high school education platform that due to the success of its model has orchestrated its expansion into higher education.

Furthermore, many professionals who are not from educational institutions have become important voices and content providers in areas such as branding, leadership, and consumption by leading YouTube channels, becoming LinkedIn's Top Voices, or by launching their own podcasts. Many executives have gone to using apps such as Audible to listen to books while working out or driving to work. These formats have become perceived as easier to fit into the dynamics of an executive's life and as facilitators of learning in adult life through a microlearning process.

Traditional schools such as Harvard have been experimenting for many years with online models designed on a sophisticated technological framework. As reported in 2015 by Fox Business, Harvard Business School offered an alternative version to its traditional classroom based on case discussions in a TV studio, promoting interaction among student from across the globe. 


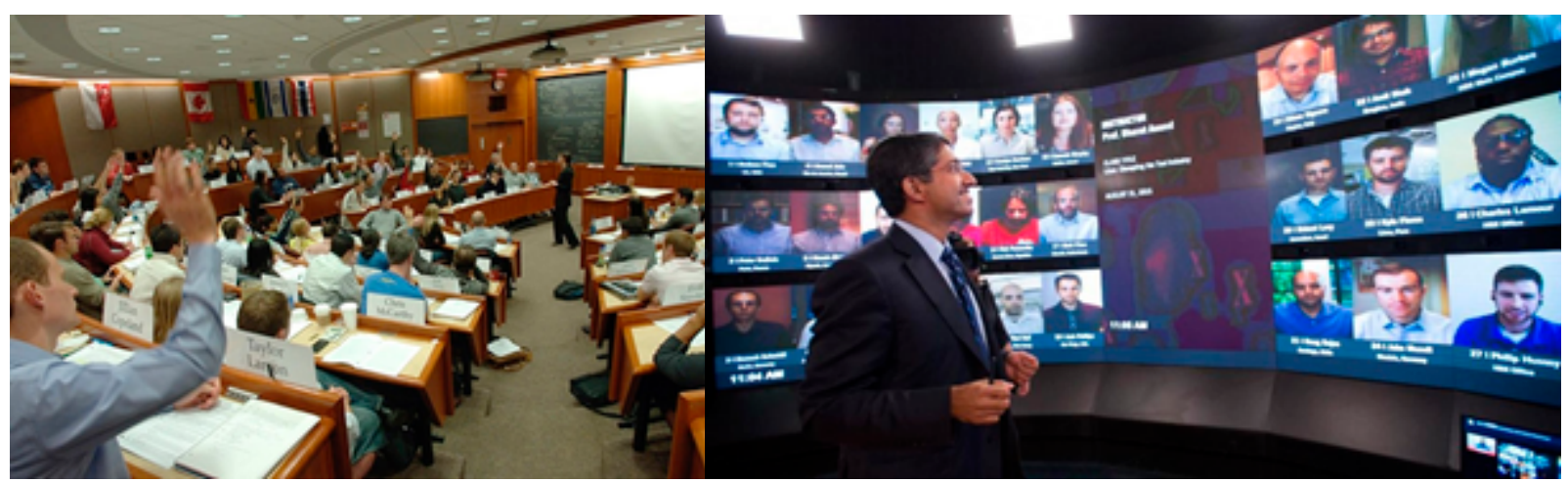

Figure 1. Harvard class using the case method in a traditional room and in an online room.

Source: Adapted from Yang, G. (2019). Is it time to retire the Harvard Case Study? Retrieved from https://poetsandquants.com/2019/10/05/is-it-timeto-retire-the-harvard-case-studyl and At Harvard's new 'virtual classroom,' students tune in to class from computers anywhere. (2015). Fox Business. Retrieved from https://www.foxbusiness.com/features/at-harvards-new-virtual-classroom-students-tune-in-to-class-from-computers-anywhere

Harvard's example was still an exception. Few were the players using a digital platform to offer a synchronous and debate-centered classroom and with the change favoring the development of behavioral and emotional skills, the so-called soft skills, along with the transmission of concepts. This movement was virtually non-existent in the Brazilian market, which seemed more familiar with DL in asynchronous formats.

Soft skills have been offered through new options, especially addressed to top leadership. They are usually synchronous and face-to-face programs based on building a solid network and unique experiences. Players such as Amana-Key offer programs from three to five days through an immersion experience with the participants getting out of their routine, favoring fun activities that are very different from the teaching standards present in classrooms of traditional teaching institutions. Hyper Island is another example of this alternative offer. It is an international school based in countries such as Brazil, Finland, Singapore, Sweden, England, and the United States offering courses of various durations, but always with an atypical classroom of an applied and customized nature centered on real and transversal projects. Other traditional players have also ventured into this segment, offering products with different formats that combine individual coaching sessions with online sessions and face-to-face meetings.

With the pandemic, many international educational institutions announced the expansion of their online portfolio or even hybrid programs, driving the expansion of digital in the offer of content relevant to the various market segments. The $100 \%$ online or DL courses were seen as a powerful mechanism of inclusion and training in mass, which is very relevant in emerging countries where there is still a large gap between the offer and preparation of the workforce. On the other hand, a discussion began on the value of the face-to-face experience because with the experimentation of a digital consumption forced by the pandemic, many potential students began to question the real value of very expensive in-person courses held at the distant and luxurious campuses of the prestigious business schools of the world. Even after the pandemic, the return to face-to-face classes may only come through a reinvention of the classroom setting.

\section{PREVIOUS EXPERIENCE IN DL}

Coppead began its incursions into DL in 2010. At the time, the school offered an MBA course through DL for the bank Banco do Brasil. It also produced video recordings for leveling content with its executive MBA. In the eyes of the teachers, however, these asynchronous teaching platforms were interesting to disseminate some content, but they did not reproduce the classroom environment, to which Coppead has always given great value. As for its online Learning Management System, Coppead has been using the AVA platform for making material available for some years, but not all teachers use the platform for interacting with students.

In short, asynchronous DL could even be complementary, but it did not seem to be a solid solution for going digital with the school's courses due to losing the teaching and learning process focused on the student and also because of the time it takes to produce the contents. Because it is a small school, the rate of producing the material could be inadequate and it would take a lot of time from teachers, compromising the quality of other activities such as research, which is fundamental to bringing innovative content into the classroom. Asynchronous DL on a large scale would move the school away from its core competencies. Synchronous DL, on the other hand, seemed 
to be a way of enabling the focus on the student and provide an alternative closer to the essence of Coppead's classroom, but it had not yet won over many supporters among the teachers. In 2019, the school underwent a major review of its strategy and it researched new teaching methods and the needs of the executive public. The lessons learned from this intense year of study would lead to designing new products. But "life is what happens while we are planning"...

\section{THE ARRIVAL OF THE PANDEMIC}

On Friday, March 13, Elaine was in a meeting in her office when the news arrived by WhatsApp that the university was suspending its activities due to the pandemic in compliance with a state decree. The meeting ended at that moment and Elaine called together all the course coordinators so that they could cancel the next classes until the school could decide on how it would operate.

Elaine had already marked a meeting with all teachers for the following Tuesday to discuss actions regarding the pandemic because since the 11th they had seen the possibility of things closing. But there was one concern that kept nagging her. Would the school's teachers, who were always very zealous for the brand and quality of teaching, accept migrating their classes to a virtual environment? She believed that there would be a lot of resistance toward this. What if they do not accept it? How long would Coppead remain without giving classes? How much would this keep students from graduating? What would happen to the school's reputation?

She arrived at the meeting on Tuesday with this concern that had only grown during the weekend. On Saturday, she acquired a Zoom license and the meeting itself already took on a new format since some of the teachers already expressed that they could not go to the school because they were part of the high-risk group. Holding such an important meeting now through a new medium could also make it even more complicated. Elaine began the meeting with a strong speech of why it was essential to make the classes go to a synchronous virtual platform at that time. Coppead could not stop.

There would be no problems for the continuity of the research, but as for the courses, the situation was potentially catastrophic. The year had just started. Most of the students had just stepped into the classroom about a month earlier. They did not know each other very well, but were excited about the course and with the integration with their new colleagues. How long would this break be? For the students, it would be an interruption of very important personal projects. Many of the master's degree students had left their jobs in order to pour themselves into their study. Also, to not prepare people during such a critical situation for the country would be to neglect the school's mission. It would be a lost year for Coppead. The dropout level in all courses would clearly increase, a problem that the school had never faced. The suspension of contracts would also be the cause of laying staff off, which would cause a loss in the school's structure in the coming years because the knowledge of the processes would be lost. And for how long would this health and economic crises last? Other schools would certainly adopt a virtual path. The scenario was daunting and Elaine had never been so worried about the school's future.

However, the way the teachers responded was laudable. The school's relevance has always been something that has motivated the group. Everyone readily understood that in order to remain relevant, adopting synchronous education needed to happen urgently. The climate was one of confidence in the teaching staff's quality and the way that they saw it was that even without the much-desired planning, everything would be fine because the motivation was enormous.

While the school was discussing its remote education options, news arrived that this modality would not be accepted at the Rio de Janeiro Federal University (UFRJ). Elaine left the meeting and consulted with an authority from the university who pointed out that the Ministry of Education had issued a ruling that day allowing for the virtualization of classes during the pandemic. The university would have to allow the classes to be virtualized for courses that already had DL. The school took into account the fact that it already used AVA in all its courses, which implied that the students had to have the technological resources to keep up with their classes. There was no time to wait for this scenario to clear up.

The next step was for the faculty to reach a joint decision as for the platform of choice and to get everyone trained so that classes could be taught in the new environment. Zoom, in addition to having an affordable cost, was incredibly similar to the possibilities of Coppead's classrooms. Classes could be divided into small groups for case discussions, similar to the school's meeting rooms located next to the training centers, students can raise their hand to organize the discussion, and it was possible to share screens and take polls. The challenge of finding a technological solution that accommodated the school's skills, which previously seemed enormous, was quickly solved. It was not necessary to have a sophisticated technology infrastructure because there was already a solution ready for the basics - the communication process. The original impression that this would require a high investment, such as in the case of Harvard, was overcome by this technology becoming a commodity. This discovery that the technology was accessible helped appease the group's insecurities. 
Now that the technology platform had been chosen, it was time to train the team to use it. Teachers who were more familiar with the technology took the lead in this process and a series of meetings took place among teachers and guests to learn about the tool and give experimental classes to colleagues. The academic department was also trained because of Coppead's rule that classes must include a secretary and an IT technician, who in this case would be in the virtual room with the teacher to provide teachers and students with assistance in the case of them having technical difficulties.

The school, which had followed a tech code of not allowing the use of technology in the classroom to not generate dispersion, needed to rethink its rules. It was necessary to guide students and the entire staff on how to behave in this virtual environment and how to better use the technology for teaching and learning. In addition to several meetings via Zoom, discussion groups over WhatsApp also helped this process, which were created to give technological support to students.

On March 23, only a few days after the decision of going to virtual classes, the school was already prepared for a return in this new environment. The classes started up again and with them the sharing of experiences among colleagues and celebrating each success case. The insecurity with a new medium gave room to being proud to belonging to an engaged team of professionals.

For the master's and doctorate degrees, the return of classes took place with very natural steps and the classes were very successful, but as for the executive education courses, the challenge was greater. The initial announcement that the classes would resume in the same format as the previous classes caused concern to the students. Meeting for eight hours a day, such as was the case in the physical classroom setting, was an exaggeration for the virtual environment in a time of pandemic. With the intent of offering a quick solution, the school did not talk to the students. They were adapting to the reality of working remotely in their organizations and living with domestic situations never experienced before. It was a mixture of professional and personal environments, children needing attention and care, insecurities, concerns, and an accumulation of tasks. Some were doctors assigned to be at the front of the line, others were on crisis committees of their organizations, and several had young children at home.

The coordinators of the executive courses apologized for their initial quick actions and now stopped to listen to the students. Because it is small and protects its reputation for excellence, the school has always kept a close connection between teachers and students. This proximity was virtually resumed through meetings of the director and coordinators of the MBA courses with the students, which allowed them to understand their new reality. Each class was able to choose the hours that they would be able to handle at that time and the entire course framework was revised to adapt to their availability. Experimental classes were offered for students to get to know the proposal. They were insecure because taking an online course was not what they had signed up for, but understood the importance of virtualization. Atypical times required breaking paradigms, and that is what happened. The classes were virtualized and offered within the limits of people's capacity without the commitment that the academic calendar would close at the end of the year, because the focus needed to be on quality. The school also made the commitment that if any class was not well evaluated by the group due to the online platform, that those classes would be done over in person in the future. The course coordinator was present at all meetings to keep in touch with the class and listen to feedback.

After the classes were resumed via Zoom, several articles appeared in the media questioning the platform's safety. Some students even let us know that this system had been banned from their company computers. Once again, the school needed to learn. It consulted with IT experts and the largest cyber security center in the United States (UTSA), and it reconfigured its security options and procedures for entering a virtual classroom. The student dropout rate was very low with a few students requesting a transfer to the second semester due to issues of reconciliation with professional responsibilities, which became more demanding.

\section{WHAT ABOUT THE FUTURE?}

Professor Vijad Goviradajan from the Harvard Business School said in a webinar that $90 \%$ of universities would close their doors within 30 years. The initial forecast that artificial intelligence would diminish the demand for higher education and that many universities would close their activities had been anticipated 20 years ago. In meetings of business school associations, Elaine had already heard that many schools would no longer exist, especially those of less relevant brands, but such a strong drop in market demand was frightening. Several questions began to pop up in her mind: How would the industry be affected by the pandemic? What was the commercial movement of the large schools abroad? Would they seek new markets to compensate for local losses? What challenges and opportunities would Coppead have with geographic expansion considering its strong local brand?

Coppead's transition to a synchronous remote environment was very natural. It was done with less planning than desired, but it brought a lot of confidence to the team. The learning of teachers and students about using 
the platforms was very fast and kept the school in line with the teaching and learning process in which it has always believed, which is centered on the student. Elaine realized that Coppead had been highly responsive in the short term, but it would be important to keep an eye on the long-term strategy. It was necessary to solidify the knowledge obtained and the school's image of innovation. There was also a sea of possibilities for creating new partnerships. But were these opportunities compatible with the reality of a small business school?

The school would continue with its virtual classes as long as the pandemic lasted, but the knowledge gained, the experimentation with the new, and the changes in people's behavior have brought new opportunities. What would be the next possibilities? What would continue to make Coppead stand out in this new world? How should the school review its portfolio to incorporate new products now considering that both teachers and students can be in the physical classroom or on a virtual platform? What new skills will the market demand after the pandemic?

There are many doubts, opportunities, and threats, but Elaine is certain of one thing - growth comes through adversity. The pandemic could be seen with discouragement, but also as an invitation to overcome. As for Coppead, Elaine is sure that the school will continue innovating.

\section{NOTES}

1. Department of Graduate Programs in Engineering at UFRJ.

2. https://www.edx.org/ (retrieved from June $26^{\text {th }}, 2020$ )

3. https://www.beacademy.com.br/ (retrieved from June $\left.26^{\text {th }}, 2020\right)$

4. https://somostera.com (retrieved from June $26^{\text {th }}, 2020$ )

5. https://conteudo.hsm.com.br/hsm-university/ (retrieved from June $26^{\text {th }}, 2020$ ) 


\section{Teaching Notes}

\section{ABSTRACT}

This teaching case describes the process experienced by Coppead, one of the main graduate schools in business in Brazil, to adapt to e-learning. The change is driven by the social isolation adopted in the country due to the COVID-19 pandemic. The case reports on the decisions that the faculty collegiate, led by the director Elaine Tavares, has needed to take to circumvent the quarantine and ensure teaching continuity at Master, Doctoral, and Executive MBA levels. The case discusses the main challenges during the transition, but most importantly highlights the strategic opportunities that this shift has offered for innovation in the coming years.

Keywords: case study; innovation; e-learning; education.

\section{DATA SOURCES}

The information in this case comes from observations and interviews with Coppead teachers and staff. Public sources such as official websites and websites specialized in business were also used. The data were collected from April to May 2020. The case structure and the teaching notes followed the recommendations of Chimenti (2020), Alberton and Silva (2018) and Roesch (2006).

\section{LEARNING OBJECTIVES}

The case was developed to be used with graduate students (master's degree or specialization course) in the disciplines of Strategy and Innovation. The case can be discussed based on the literature of ecosystems, scenarios, and innovation. Students should consider strategies and actions for Coppead to enter into the virtual environment, discussing how much this change will affect the school's

\section{RESUMO}

Este caso de ensino descreve o processo de adaptaçáo para a virtualizaçáo do ensino no Coppead, uma das principais escolas de pós-graduação em administração no Brasil. A mudança ocorre impulsionada pelo isolamento social adotado no país por conta da pandemia de COVID-19. O caso relata as decisóes que o colegiado de professores, liderado pela diretora Elaine Tavares, precisou tomar para contornar a quarentena e garantir a continuidade das aulas no Mestrado, Doutorado e MBA Executivo. Os desafios dessa transição são discutidos, porém mais importante que isso são as oportunidades estratégicas que essa experiência abre para a inovação da escola nos anos futuros.

Palavras-chave: caso de ensino; inovação; ensino remoto; educação.

future. It can also be applied to courses on education management and active teaching practices.

Using teaching cases aims to develop in the participants skills of analysis, argumentation, and decisionmaking (Mauffette-Leenders, Erskine, \& Leenders, 1997), enabling the student's active involvement in the teachinglearning process. This case has the following specific educational objectives:

(a) Understand how the traditional education industry in particular is facing a transition into the digital world.

(b) Discuss how external effects can drive innovation, removing traditional barriers to adopting and modifying the perception of risk.

(c) Explore the impact of innovations on business ecosystems by addressing the challenges of those holding to the status quo.

(d) Use scenario analysis to strategically plan the future of an organization. 


\section{DISCUSSION QUESTIONS}

Considering the academic objectives proposed for the case, we suggest the following discussion questions:

- What are the main challenges faced by Coppead during the transition to remote education?

- How does the pandemic impose adopting remote teaching in the education ecosystem?

- Does adopting new digital technologies seem to be a good strategy for any business school?

- How should Coppead design its post-pandemic action while taking advantage of the experience gained from going to digital classrooms while still keeping the learning student-centered?

\section{CASE APPLICATION PLAN}

When applying the case in the classroom, it is essential that the students have been given guidance about the method and its stages and about the importance of everyone's commitment to create an environment favorable to discussion and to developing arguments (MauffetteLeenders et al., 1997). The teacher should encourage the students to put themselves in the place of the story' protagonist, Coppead's director Elaine Tavares, and try to understand her dilemmas and the issues involved in the decision to be taken. It is also essential to read beforehand the bibliography recommended as presented in the References.

The following three stages are recommended in accordance with the structure of the case method: (a) individual reading and analysis of the case, complemented by the recommended readings; (b) discussion of the case in small groups; and (c) discussion with all the students together mediated by the teacher. It is suggested that the discussion of the case with everyone together should last 90 minutes distributed in the following way:

- 10 min: Opening and overview of the situation;

- 20 min: Analysis of Coppead and its challenges with remote teaching;

- 20 min: The education ecosystem;

- 25 min: Transition to digital and the future of education;

- 15 min: Closing with recommendations.

\section{OPENING OF THE PLENARY DISCUSSION OF CASES}

The teacher could begin the discussion in plenary by asking the students what was the main dilemma faced by
Coppead's director, which will allow the teacher to align the dilemma before the discussion in small groups. While some students will objectively address the dilemma presented (how and if Coppead should enter into remote education), some may bring up broader issues such as the future of education organizations in general, given the advent of disruptive innovations in education.

\section{1) Challenges of remote education for Coppead}

After a discussion in small groups, the teacher could begin the discussion by asking if the pandemic is a threat or an opportunity for Coppead. Students can be encouraged to choose one of the options, such as in a poll, and some should be chosen to justify their answer. The debate tends to get heated as students may consider the pandemic to be a serious threat, taking into account the potential reduction in students and revenues and the threat of new entrants. On the other hand, some may argue that the pandemic brings opportunities because barriers to innovation traditionally found in traditional firms open up space for innovation. The concepts explored by Day and Schoemaker (2000) on the pitfalls of the dominant firms and Christensen (1997) on the dilemma of the innovator can be explored, bringing up a discussion on how remote education is an incremental or disruptive innovation.

A careful analysis will show that e-learning has a set of emerging technologies for its potential to create new markets and new business models. It can also be considered disruptive due to its potential to deliver a better experience in terms of teaching personalization and convenience at a relatively lower cost due to the scalability of the existing solutions.

At this moment, the teacher may suggest for the students to reflect on Coppead's reality, which will make it clear that several of these costs do not cease to exist since the school will probably not shut down its facilities and that much of the costs of its facilities are fixed.

In addition to this aspect, the teacher may ask students about who would be the drivers and gatekeepers of innovation and what would be their reasons, bringing up a discussion on the barriers raised by various stakeholders in the education ecosystem such as teachers themselves, regulators in government and at UFRJ itself, in addition to students and society in general. Figure 2 shows the modeling of Rodrigues, Chimenti and Nogueira (2021) on the factors that drive or prevent e-learning adoption. 


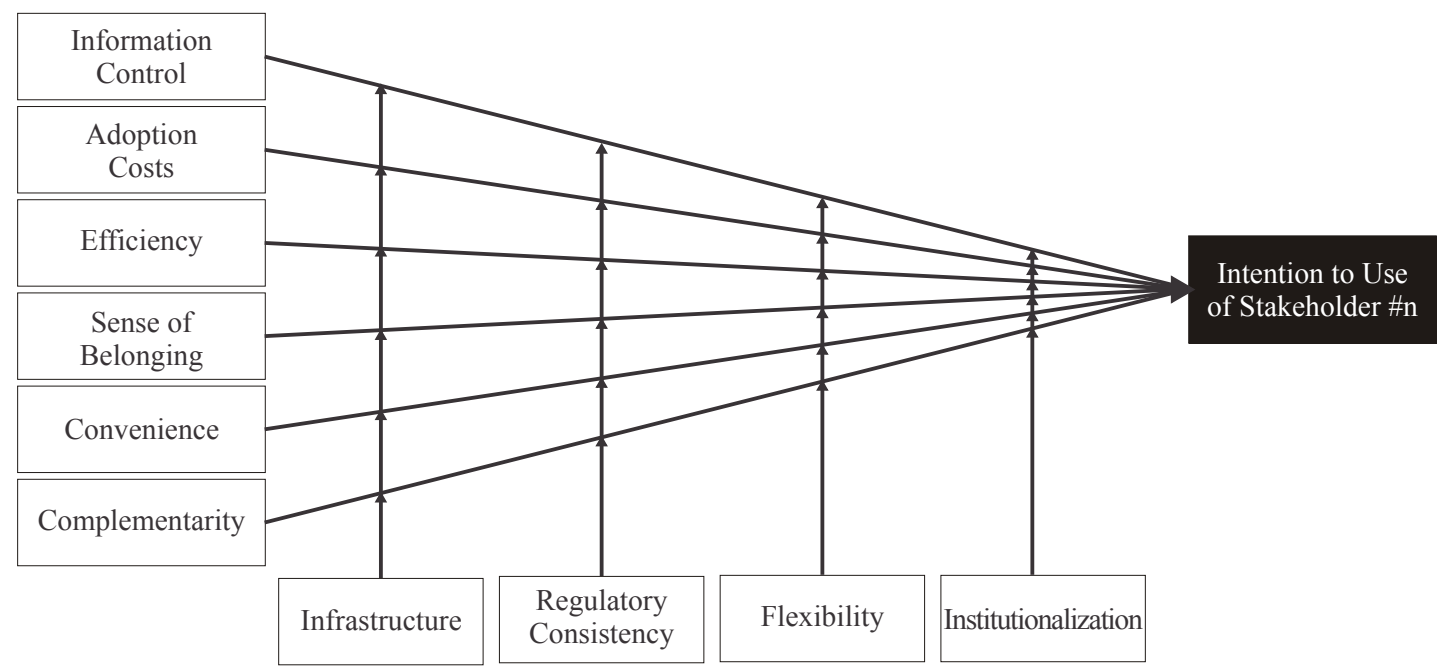

Figure 2. Factors for adopting e-learning;

Source: Adapted from Rodrigues, M. A., Chimenti, P., \& Nogueira, A. R. R. (2021). An exploration of eLearning adoption in the educational ecosystem. Education and Information Technologies, 26, 585-615. https://doi.org/10.1007/s10639-020-10276-3

\section{2) Education ecosystem}

Another contribution from Rodrigues et al. (2021) for discussing adopting e-learning deals with the perception that it does not have to do with only one player, but with an adoption at multiple levels by multiple stakeholders.

The teacher could introduce this discussion by asking the class who decides to adopt e-learning. With the emergence of several players in the discussion, the concept of a business ecosystem can be introduced, pointing to the relevance of having a broad understanding of the ecosystem in which an organization is inserted before preparing its strategy.

Based on this observation, the teacher can build the education ecosystem (see Figure 3 for an ecosystem design suggestion) together with the students, encouraging participants to reflect which organizations and individuals are part of it and which connections exist or are absent between these elements.

An analysis of the ecosystem in the classroom could show the entry of new players in the education sector, reinforcing how the industry's barriers have been diluted, bringing new heavyweight participants to the game such as Google, which have the power to change various rules. It also helps identify potential partners for traditional schools such as Coppead during its entrance into this virtual world such as platform developers, game developers, and others.

\section{3) Scenarios for the future of education}

Based on the ecosystem's design, the teacher can cause students to think about the future of education by using scenarios. The reading of Garvin and Levesque (2005) or Schoemaker (1995) may help in this discussion.

Scenario planning involves several elements that together form a multifaceted vision of the future. Instead of pointing to a single path, the idea is to work with multiple futures, considering the strategic possibilities that open up in the sector and preparing the organization for multiple future possibilities. The process begins with defining the geographic scope and time horizon, defined here as Brazil within a 10 -year horizon. From this definition, the main forces of change are raised, which are then combined with the future scenarios. The forces of change can be categorized as predetermined or uncertain with the first being called 'trends' and the second 'uncertainties.'

The key trends for the education ecosystem can be identified by students based on their experiences and reading of cases such as digital inclusion, mobility, the falling of geographical barriers, the abundance of offers, among others. 


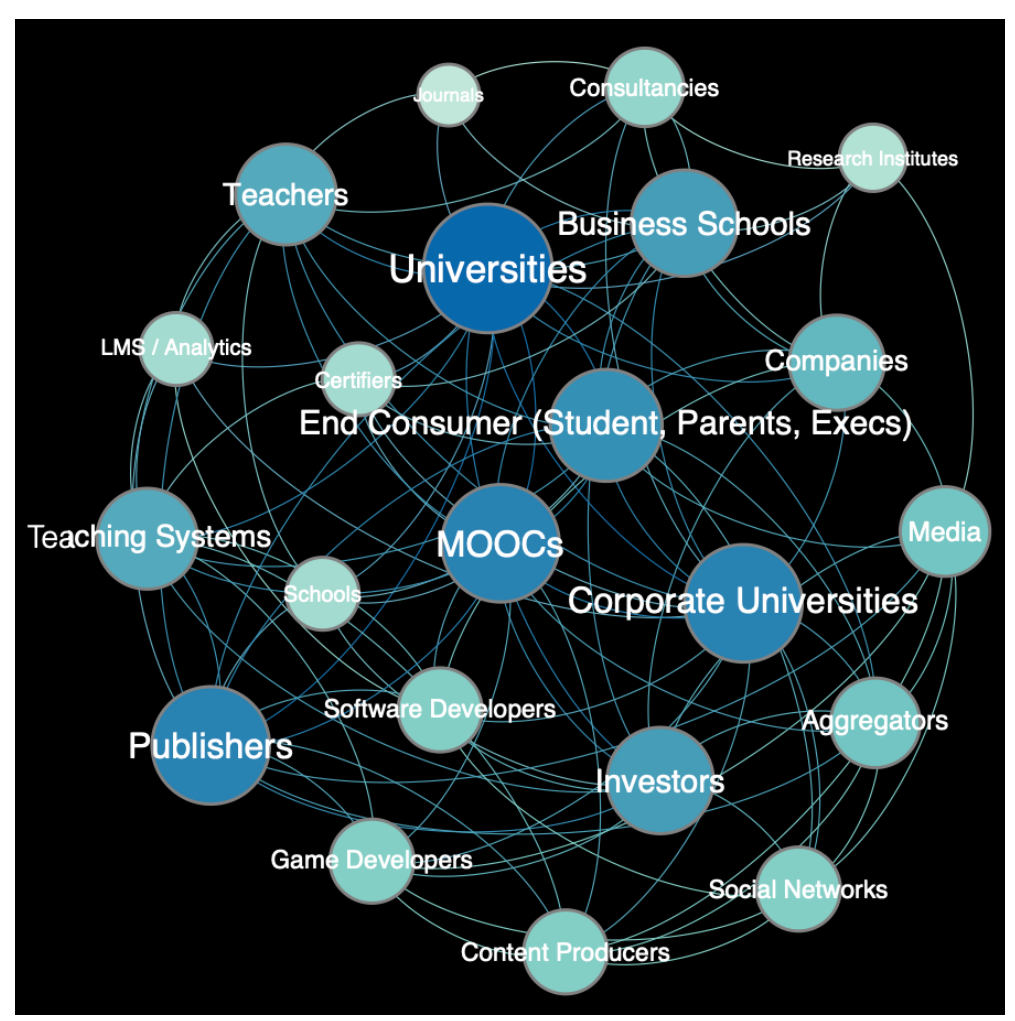

Figure 3. Education ecosystem.

Source: Chimenti, P. C. P. S., Rodrigues, M. A. S., \& Nogueira, A. R. R. (2015, June). O futuro da educaçáo: Uma análise de cenários. Anais do Encontro de Estudos em Estratégia - 3Es, Brasília, Brazil, 7.

Once these predetermined factors have been identified, the other forces of change over which doubts are expressed are classified as uncertainties. It is important to point out that for scholars who work with the methodology of planning with scenarios, the uncertainties are the crux of the matter as they actually bring a difference to the planning (Schoemaker, 1995; Garvin \& Levesque, 2005). This is because, although most companies plan to look only at trends, it is the uncertainties that allow an actually strategic view that considers future possibilities that could be ignored by the organization. Thus, their analysis helps companies observe phenomena that were not on their radar, to deal with the unknown, and to identify opportunities in change. This is clear without the intention of seeing beforehand all the uncertainties.

It is important to highlight that the teacher and students should be free to choose the uncertainties for the ecosystem described, as this strategic analysis is a creative exercise with no right or wrong answers. The scenarios presented in this teaching note are not intended to prescribe a correct answer, but to assist the teacher with support material for this exercise of creativity with the class. The following scenarios come from the research of Chimenti,
Rodrigues and Nogueira (2015), who mapped the following uncertainties:

Massification vs. Customization: Dichotomy between personalized virtual teaching and mass face-to-face teaching. Online platforms offer a far greater reach than the traditional classroom, providing education to people who previously had no access to university education due to geographical, routine, or income issues. Another point is a gradual change in the perception of students and companies about the quality of distance learning. Students can discuss how the COVID-19 pandemic and quarantine pushed the entire education ecosystem into virtualization much faster. However, the intensity of use and the e-learning models that will be adopted in the future still remain uncertain.

Market Certification vs. Diploma: The second uncertainty mapped in the research deals with the possibility that in the future a college degree be replaced by a certification that attests to a person's knowledge, regardless of how this knowledge was acquired. Thus, the traditional format of graduation with a diploma at the end would be replaced by certification tests such as those taken by the lawyers to be approved by the Bar Association. In a possible future, the current format of college degrees will be a thing of the past with students building their own personal education track 
record and the market only requiring a proof of knowledge and skills without a concern regarding the process. This possibility is driven by the decreasing dependence that students have on teachers as a source of knowledge. Those interviewed unanimously highlight the difficulty in keeping the attention of students and in teaching using traditional methods. In this sense, the diploma tends to lose its value in the medium term, being replaced by new learning methodologies.

According to the scenario method, each critical uncertainty is reduced to a single continuum or axis with extreme possibilities placed diametrically opposed. The two axes are consequently combined to create a $2 \times 2$ matrix with four different quadrants representing futures to be explored. The goal is to end with only a few 'futures' that are highly contrasting among themselves. The futures that resulted from the interaction of the critical uncertainties are called scenarios. They are plausible and alternative hypotheses about how the world could become, specially designed to highlight risks and opportunities for the organization. Scenarios challenge participants to think, inciting a deeper appreciation of several factors that can shape the future. There are no right or wrong scenarios.

The combination of the uncertainties described above gave rise to the scenarios presented in Figure 4, in which the trends identified are present.

Each scenario is named in such a way that it can be easily identified by the participants in the planning process and usually simple names are chosen associated with their meaning. In this case, well-known film names were used. Likewise, descriptions were produced that summarize the main characteristics of each one. According to the method, no probabilities are associated with the scenarios. The goal is not to try to predict a single future, but to prepare the organization for each one of them.

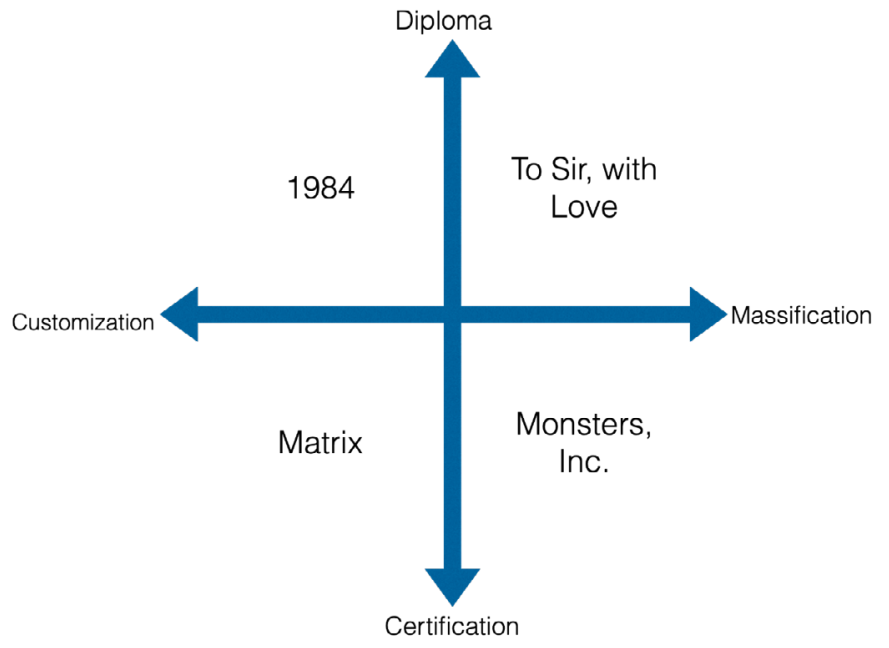

Figure 4. Scenarios for the future of education.
The narratives for each of the four scenarios are presented below.

Scenario 1: To Sir, with Love. This is the scenario closest to the current practice in the industry. In it, the diploma continues to have value and classes continue to take place for the most part in the physical classroom in an expository, standardized, and mass model. However, due to advances in digital inclusion and mobility, the student attention is becoming increasingly difficult to maintain, so new technologies are incorporated as complements to classroom education.

Scenario 2: Monsters, Inc.: In this scenario, the classroom remains important and teaching remains uncustomized, being distributed massively to many students. The tarnishing of the traditional university model, however, results in the growth of certifying entities, which begin to certify to the market that a particular candidate fulfills the technical requirements and has the skills necessary to perform a function. In the end, the companies themselves carry out this assessment.

Scenario 3: Matrix. As opposed to Scenario 1, this is undoubtedly the most disruptive for the institutions that lead the industry today. In this future, accelerated by the pandemic, the main learning platform is online and the physical classroom is considered something outdated. Technology allows students to attend classes, discuss with each other, and interact with teachers from their homes as if they were in the same environment. With the help of the platform, students create for themselves a fully customized set of disciplines, bringing together the knowledge they need for their professional future. The contents are delivered in the way that the student chooses - audiovisual, text, pure audio, etc. The traditional universities have been replaced by certifying bodies that attest for each type of employer the competencies of their candidates. The important thing for the market is what you know, not how you learned it.

Scenario 4: 1984. In this scenario, many universities have migrated to online, adapting what they offer and maintaining their relevance in the ecosystem. Partnerships between physical universities and MOOCs allow for an expansion of the offers and a more flexible set of disciplines. Teaching is more personalized, adjusting the delivery of content to the needs of the students. The university degree continues to be important with the creation of a greater range of possibilities and more accessibility in relation to price and geographical reach.

Although it is difficult for the scenarios to reach fruition in their extreme formats, they are useful for organizations that operate in the ecosystem and intend to maintain their relevance in the future. The idea is that by circumscribing future possibilities, the organization 
is prepared for whatever may take place regarding any of the four scenarios identified. To be relevant to each of them, it will be necessary to develop or acquire skills and resources that may not exist in the organization today. One virtue of the method is to indicate in advance actions to be taken so that the university is properly positioned in each of the four futures. Preparing does not imply immediately making investments, but identifying partners and suppliers with whom future contracts can be closed (if possible, exclusively) within a time frame that is adequate to the horizon estimated in the planning. This approach is of real options, which is common in high value projects with components of uncertainty, such as oil and energy (Day \& Schoemaker, 2000).

\section{4) What should be done?}

At this point in the discussion, the teacher should leave the macro focus (ecosystem) and return to Coppead and the protagonist of the case. From the scenarios considered, how can Elaine Tavares prepare the school for the future? It is important to remind the students that the purpose of this exercise is not to choose a future, but to prepare for all of them.

This strategy begins with the assessment of critical success factors for each scenario. Students will quickly identify which scenario is easiest (To Sir, with Love) and which one is the most challenging (Matrix) for the school. Given the time constraints of a class, it is recommended to work on the critical factors of these two extreme scenarios, emphasizing with the class their similarities and especially their differences.

In the To Sir, with Love scenario, students will realize that most of the critical success factors such as reputation, highly qualified faculty, the best students, among others, are already a part of Coppead. On the other hand, the Matrix scenario may require very distinct characteristics such as an interactive digital platform, mastering of skills in audiovisual content creation, a broader communication for creating a global brand, since the competition also becomes global, scalability of the services, and an interaction with students that becomes much more similar to coaching than a traditional class.

In this scenario, Coppead, like all traditional educational institutions, needs to be reinvented and a 'forced' entry into the digital environment seems to be a positive outcome from the pandemic, as it makes the school move forward and evolve in developing new skills.

\section{CLOSING THE CASE}

The teacher can bring the discussion to a close by breaking down how Coppead entered into the virtual environment, as described below, while reinforcing the motto "crises are opportunities." It should be stressed that the future strategic choices of the school will strongly influence its ability to respond to future challenges by building the necessary skills in the education ecosystem of the future.

\section{CASE'S LEVEL OF DIFFICULTY}

The case's level of difficulty was defined based on the proposal of Erskine, Leenders and Mauffette-Leenders (1998). According to the authors, the cases present different levels of difficulty in three dimensions: analytical, conceptual, and presentation. Each of them is subdivided into three levels of difficulty forming the so-called 'case difficulty cube.' The analytical dimension has to do with the nature of the student's task when faced with the case's dilemma, the conceptual dimension refers to the complexity of the concepts involved, and the presentation dimension covers the amount and quality of the information that is contained in the case. The classification of the present case is shown in Table 1.

Table 1. Case's level of difficulty.

\begin{tabular}{lcl}
\hline Dimension & $\begin{array}{c}\text { Level of } \\
\text { difficulty }\end{array}$ & Reasons \\
\hline Analytical & 2 & $\begin{array}{l}\text { The case presents the dilemma of Coppead during the transition to online education. As a basis for the dilemma, } \\
\text { the student must analyze the information brought to the case and propose well-founded solutions. }\end{array}$ \\
$\begin{array}{l}\text { Conceptual } \\
\text { Presentation }\end{array}$ & 2 & The case analysis involves the articulation of different concepts such as platforms, ecosystems, and scenarios.
\end{tabular}

Note. Based on Erskine, J. A., Leenders, M. R., \& Mauffette-Leenders, L. (1998). Teaching with cases. London: School of Business Administration, The University of Western Ontario. 


\section{REFERENCES}

Alberton, A., \& Silva, A. B. (2018). Como escrever um bom caso para ensino? Reflexóes sobre o método. Revista de Administração Contemporânea, 22(5), 745-761. https://doi.org/10.1590/1982-7849rac2018180212

At Harvard's new 'virtual classroom,' students tune in to class from computers anywhere. (2015). Fox Business. Retrieved from https://www.foxbusiness.com/features/at-harvardsnew-virtual-classroom-students-tune-in-to-class-fromcomputers-anywhere

Chimenti, P. C. P. S., Rodrigues, M. A. S., \& Nogueira, A. R. R. (2015, June). O futuro da educação: Uma análise de cenários. Anais do Encontro de Estudos em Estratégia - 3Es, Brasília, Brazil, 7.

Chimenti, P. C. P. de S. (2020). Reflexões sobre Casos de Ensino Memoráveis. Revista de Administraçâo Contemporânea, 24(5), 376-379. https://doi.org/10.1590/1982-7849rac2020200102

Christensen, C. M. (1997). The Innovator's Dilemma: When new technologies cause great firms to fail. Boston, Massachusetts: Harvard Business Review Press.

Day, G., \& Schoemaker, P. (2000). A different game. In G. S. Day, P. J. H. Schoemaker, \& R. E. Gunther (Eds.), Wharton on managing emerging technologies (Chap. 1). New York: Wiley.

Erskine, J. A., Leenders, M. R., \& Mauffette-Leenders, L. (1998). Teaching with cases. London: School of Business Administration, The University of Western Ontario.
Garvin, D. A., \& Levesque, L. C. (2005, November). A Note on Scenario Planning. Harvard Business School Background Note 306-003, November 2005. Retrieved from https://www.hbs.edu/faculty/Pages/item.aspx?num=32841

Mauffette-Leenders, L. A., Erskine, J. A., \& Leenders, M. R. (1997). Learning with Cases. Ontario: University of Western Ontario.

Rodrigues, M. A., Chimenti, P., \& Nogueira, A. R. R. (2021). An exploration of eLearning adoption in the educational ecosystem. Education and Information Technologies, 26, 585-615. https://doi.org/10.1007/s10639-020-10276-3

Roesch, S. M. A. (2006, September). Notas sobre a construção de casos para ensino. Encontro Nacional da Anpad, 2006, Salvador, 30. Retrieved from http://www. anpad.org.br/eventos.php?cod evento $=1 \& \operatorname{cod}$ edicao $\underline{\text { subsecao }=149 \& \operatorname{cod} \text { evento edicao }=10 \& \operatorname{cod} \text { edicao }}$ trabalho $=5497$

Schoemaker, P. J. H. (1995). Scenario planning: A tool for strategic thinking. Sloan Management Review, 36(2), 25-40. Retrieved from https://www.researchgate.net/ publication/220042263 Scenario Planning A Tool for Strategic Thinking

Yang, G. (2019). Is it time to retire the Harvard Case Study? Retrieved from https://poetsandquants.com/2019/10/05/ is-it-time-to-retire-the-harvard-case-study/ 


\section{Authorship}

\section{Roberta Dias Campos}

Universidade Federal do Rio de Janeiro, Instituto COPPEAD de Administração

Rua Pascoal Lemme, no 355, Cidade Universitária, 21941-918, Rio de Janeiro, RJ, Brazil.

E-mail address: roberta.campos@coppead.ufrj.br

(1) https://orcid.org/0000-0002-7091-7901

\section{Elaine Tavares}

Universidade Federal do Rio de Janeiro, Instituto COPPEAD de Administração

Rua Pascoal Lemme, no 355, Cidade Universitária, 21941-918, Rio de Janeiro, RJ, Brazil.

E-mail address: elaine.tavares@coppead.ufrj.br

(1) https://orcid.org/0000-0002-1107-2101

\section{Paula Castro Pires de Souza Chimenti*}

Universidade Federal do Rio de Janeiro, Instituto COPPEAD de Administração

Rua Pascoal Lemme, no 355, Cidade Universitária, 21941-918, Rio de Janeiro, RJ, Brazil.

E-mail address: paula.chimenti@coppead.ufrj.br

(1) https://orcid.org/0000-0002-6492-4072

\section{Leonardo Marques}

Universidade Federal do Rio de Janeiro, Instituto COPPEAD de Administração

Rua Pascoal Lemme, no 355, Cidade Universitária, 21941-918, Rio de Janeiro, RJ, Brazil.

E-mail address: leo.marques@coppead.ufrj.br

(1) https://orcid.org/0000-0001-8960-8191

* Corresponding Author

\section{Copyrights}

RAC owns the copyright to this content.

\section{Funding}

The authors reported that there is no financial support for the research in this article.

\section{Authors' Contributions}

$1^{\text {st }}$ author: conceitualização (equal); curadoria de dados (equal); redação - rascunho original (equal); redação - revisão e edição (equal); supervisão (equal); validação (equal).

$2^{\text {nd }}$ author: conceitualização (equal); curadoria de dados (equal; redação - rascunho original (equal); redação - revisão e edição (equal); supervisão (equal); validação (equal).

$3^{\text {rd }}$ author: conceitualização (equal); curadoria de dados (equal); redação - rascunho original (equal); redação - revisão e edição (equal); supervisão (equal); validação (equal).

$4^{\text {th }}$ author: conceitualização (equal); curadoria de dados (equal); redação - revisão e edição (equal); supervisão (equal); validação (equal).

\section{Conflict of Interests}

The authors have stated that there is no conflict of interest.

\section{Peer Review Method}

This content was evaluated using the double-blind peer review process. The disclosure of the reviewers' information on the first page, as well as the Peer Review Report, is made only after concluding the evaluation process, and with the voluntary consent of the respective reviewers and authors.

\section{Plagiarism Check}

The RAC maintains the practice of submitting all documents approved for publication to the plagiarism check, using specific tools, e.g.: iThenticate.

\section{Data Availability}

RAC encourages data sharing but, in compliance with ethical principles, it does not demand the disclosure of any means of identifying research subjects, preserving the privacy of research subjects. The practice of open data is to enable the reproducibility of results, and to ensure the unrestricted transparency of the results of the published research, without requiring the identity of research subjects. 